O. Senyk, Ph.D, Assist.

Ivan Franko National University of Lviv, Lviv

V. Abramov, Ph. D, Assist.

Taras Shevchenko National University of Kyiv, Kyiv

M. Hrechkosiy, Ph. D, Assist.

I. I. Mechnicov National University of Odessa, Odessa

V. Bedan, post-graduate

K. D. Ushinskiy National Pedagogical University of South Ukrainian, Odessa

A. Bunas, PhD, Assoc. Prof.

Oles Honchar National University of Dnipro, Dnipro

O. Lutsenko, PhD, Assoc. Prof.

V. N. Karazin National Universityof Kharkiv, Kharkiv

\title{
DYNAMICS OF THE TIME PERSPECTIVE OF STUDENTS YOUTH OF THE SOUTH-EASTERN AREAS OF UKRAINE IN THE CONDITIONS OF SOCIOECONOMIC CHANGES
}

This paper focuses on the time perspective dynamics of the Ukrainian 17-24-year-olds which reside in the south-eastern regions of Ukraine, such as Kharkov, Dnepropetrovsk and Odessa regions, during the period 2012-2015. The study included areas bordering the zone of military conflict, or those that are an area of great national importance and therefore are a strategic area in military operations, which can begin there. Al subjects filled out a personal data questionnaire (age, gender, place of residence) and the Zimbardo Time Perspective Inventory (ZTPI) in the Ukrainian-language adaptation by A. Senik or the Russian-language adaptation by A. Syrtsova. Thus, the research has covered three periods which differ in social, political and economical stability: before Maidan, during Maidan and the one started with onset of armed conflict in the Eastern regions of the country. The temporal perspective of young people, measured during these periods, may also differ because of changes in the social and material parameters of life. The results have shown that during the aforementioned period future time orientation decreases, whilst the numbers of present fatalistic and past negative time orientations as well as a negative interpretation of past events increase with onset of armed conflict in the Eastern regions of the country. The significance of time orientations does not differ in the period before the Maidan and in the Maidan period, and grow only in the period from the outbreak of the military conflict - simultaneously with significant changes in the social and material parameters of the population life living near the military conflict zone. The results obtained - a decrease in the setting of long-term goals, an increase in fatalism (helplessness) and a negative assessment of the past - may be the result of the young people traumatic experience, through the prism of which past, present and future events of one's own life are evaluated.

Keywords: time perspective, time orientation, Maidan, Eastern Ukraine.

Bulletin of Taras Shevchenko National University of Kyiv.

Series "Psychology". № 2(9), pp. $72-76$ (2018)

удК 159.99

DOI: https://doi.org/10.17721/BSP.2018.2(9).18
ISSN 1728-3817

(C) Taras Shevchenko National University of Kyiv,

Publishing Center "Kyiv University", 2018

Г. Січкар, студ.
Київський національний університет імені Тараса Шевченка, Київ

\section{ДИСФУНКЦІОНАЛЬНІ МЕХАНІЗМИ АДАПТАЦІї ЯК НАСЛІДОК ПАТОЛОГІЧНИХ ВЗАЄМИН ДОНЬКИ ІЗ МАТІР'Ю}

Піднімається питання про дисфункціональні механізми адаптації у жінок як наслідок патологічних взаємин із матір'ю. Особлива увага приділяється таким із них: міжособистісна залежність, депресія, тривожність, фрустрація, агресія, ригідність.

У результаті дослідження було доведено, що у представниць із неповних сімей усі задані показники (міжособистісна залежність, депресія, тривожність, фрустрація, агресія, ригідність) є більш вираженими. Відсутність у матері постійного партнера (на ряду з іншими факторами, що висвітлені у статті) каталізує та сприяє запуску процесу формування патологічних взаємин між донькою та матір'ю, що у свою чергу стає основою формування дисфункціональних механізмів адаптації у доньки як вираження материнської травми. Це може бути пояснено тим, що донька в даних умовах стає єдиним об'єктом проекцій материнських страхів, бажань та незадоволених потреб, крім того, вона стає єдиним джерелом любові.

Ключові слова: материнська травма, комплекс матері, дисфункціональні механізми адаптації, проекція, "псевдоособистість".

Материнство є невід'ємною частиною нашого життя, оскільки саме у процесі спілкування та взаємодії з матір'ю формується людська особистість. Моделі поведінки та виховання, закладені батьками ще в дитинстві, переносяться і в доросле життя та передаються наступним поколінням. Згідно із К. Белл, у кожній жінці у вигляді "Я" та об'єктних репрезентацій "накопичені" різноманітні взаємодії між матір'ю і дочкою. У круговому русі, починаючи 3 народження, взаємодія між матір'ю і дочкою розгортається як відновлення та переоформлення взаємин, що вже мали місце між двома жінками попереднього покоління [1]. Це ланцюгова реакція, яка визначає якість психічного життя цілих поколінь. Проте під тягарем соціокультурних уявлень та кліше так важко розгледіти сутність дочірньоматеринських стосунків, що проходять червоною ниткою через усе життя і являють собою джерело та підґрунтя формування особистості людини. Багато авторів займались розробкою даного питання, серед них: К. Белл, К.Г. Юнг, М. Лейзінгер-Болебер, В. Штерн, А. Міллер, Б. Уебстер, Е. Каролін тощо.

Метою даної статті $€$ висвітлення поняття "материнська травма" та виявлення дисфункціональних механі- змів адаптації жінок, що є наслідком патологічних взаємин із матір'ю. Для досягнення даної мети були поставленні такі завдання

- висвітлити значення материнства для розвитку особистості дитини;

- проаналізувати теоретичні дані про дисфункціональні механізми адаптації стосовно розладу материнсько-дочірніх взаємин;

- визначити вияви дисфункціональних механізмів адаптації як вираження патологічних стосунків доньки 3 матір'ю.

Методи дослідження: теоретичні - аналіз, систематизація та узагальнення психологічних даних із проблеми дослідження; емпіричні - психодіагностичні методики: Опитувальник міжособистісної залежності Р. Гіршфільда, Методика диференціальної діагностики депресивних станів Зунге, Методика діагностики самооцінки психічних станів Айзенка

Якщо дитина росла, бачачи в матері відображення себе і відчуваючи, що мати дбає про її розвиток, то в ній з роками може розвинутися здорова самосвідомість. В оптимальному випадку саме мати створює доброзич- 
ливу емоційну атмосферу і з розумінням ставиться до потреб дитини. Не схильна до вияву любові, мати також може сприяти розвитку самосвідомості дитини. Вона просто не повинна перешкоджати цьому процесу. Тоді дитина може отримати в інших людей те, чого ӥй не дала мати. Так, А. Міллер стверджує, що дитина має вражаючу здатність використовувати для свого розвитку емоційні переживання оточуючих. "Під здоровою самосвідомістю мається на увазі тверда впевненість у тому, що пережиті почуття й бажання $є$ складовою частиною власного Я" [3, с. 62]. Це природний стан, що допомагає зрозуміти власні почуття і бажання, дозволяє людині знайти внутрішню опору й поважати саму себе. За даних умов дитина може жити власним життям: сумувати, впадати у відчай і потребувати допомоги, не боячись, що своєю поведінкою вона спричинить комусь незручності. Вона може відчувати страх, якщо їй загрожують, і злитися, якщо її бажання не задовольняються. Вона знатиме не тільки чого не хоче, але і чого хоче, і може це відкрито висловити [3].

Із пробудженням Я-свідомості зв'язок між матір'ю та дитиною слабшає, і свідомість вступає в опозицію за диференціацією Я і матері. Тоді всі архетипові, казкові та містичні якості, пов'язані з образом матері, слабшають, а особисті риси стають дедалі чіткішими. Тому вплив, який матері справляють на дітей, розділяють на дві групи. Той, який відповідає рисам характеру і відносинам, які дійсно властиві матері - К.-Г. Юнг - бачив причину інфрантильного неврозу в матері, уважав, що дитина скоріше схильна розвиватися нормально, ніж невротично, і в більшості випадків причини відхилень можуть бути пов'язані з батьками, особливо з матір'ю; і той, що пов'язаний із рисами, які по суті $€$ фантастичними, архитипічними проекціями дитини - 3. Фрейд стверджував, що реальна етіологія неврозів полягає не у травматичних ефектах, а в особливому розвитку дитячої уяви [7].

На думку К. Ельячефф, кожна жінка, що стала матір'ю, змушена протистояти двом протилежним моделям здійснення материнської ролі, відповідним двом найбільш суперечливим розпорядженням: будь матір'ю або будь жінкою. Ці протилежності можуть уживатися в одній жінці, в одній ідентичності, в одному тілі. Трапляється так, що в діапазоні варіантів, розташованих між двома цими полюсами, деякі дотримуються серединної позиції, вірніше сказати, їм вдається змінювати і коригувати свою позицію відповідно до кожного життєвого віку, в який вони вступають. У той самий час більшість жінок усе-таки знаходяться по один, або по інший бік барикад: більшою мірою мати, ніж жінка; або переважно жінка, ніж мати [2, с. 5].

Більшою мірою мати, ніж жінка - поведінку матері такого типу коротко можна охарактеризувати таким чином. При народженні дитини, матір виявляє "безмежну любов", що частіше за все є нічим іншим, як шаленим бажанням мати об'єкт обожнювання, об'єкт для повного зрощення в любові (симбіоз). Оскільки це дівчинка, матір вільна проектувати на неї всі свої бажання і недосягнені цілі, за К. Ельячефф це можна назвати "нарцисичним зловживанням". Бачачи в дівчинці себе, матір не помічає її власних бажань і поривів, приписує їй лише ті емоції та почуття, які вважає за потрібне. Зазвичай, більшою мірою мати, ніж жінка після народження дитини повністю втрачає інтерес до чоловіка, який уже власне "виконав свою функцію". Вона буквально витискає його із власного простору та простору дочки. "Витіснення третього" призводить до такого собі платонічного інцесту між дочкою та матір'ю. Це залежні стосунки між матір'ю та "вічною дитиною", при чому вони перебувають не в рівних позиціях. Оскільки ініціатором і модератором цих відносин є матір, вона ідентифікується з дочкою і будь-які спроби чада вийти з-під тіні матері сприймаються нею як загроза власній особистості. Дитина ж пристосовується до матері, за що отримує сурогат любові, якої ніколи не буде достатньо.

Переважно жінка, ніж мати - матері такого типу в своєму житті ставлять акцент на що завгодно, тільки не на материнство. Дитина залишена на обочині інтересів матері, почуває себе винною в цьому і цей комплекс відносин має тенденцію відтворюватись протягом усього життя. Цікаво, що навіть негативне ставлення матері вважається за краще, ніж байдуже, тому зазвичай діти, обділені увагою матері, виростають "складними" і це виливається в різні проблеми особистісного і соціального плану [2].

Частіше за все причиною патологічних материнськодочірніх стосунків $€$ власні незадоволені потреби матері. Мати, народивши дитину, може несвідомо відчути, що у неї нарешті $€$ хтось, хто буде безумовно її любити. Тоді вона неусвідомлено спробує за допомогою дитини задовольнити їх [5]. Матір не створює умов, в яких дитина змогла б висловити свої почуття і відчуття. Дитина через страх утратити любов матері починає приховувати свої емоції й вимушено витісняє їх у несвідоме. У результаті такі люди позбавлені цілої палітри емоційних переживань. Пристосування до батьківських потреб часто призводить до перетворення дитини у "псевдоособистість", до розвитку "псевдо Я". Донька поводиться так, як від неї хочуть, і поступово цей тип поведінки починає визначати всі її вчинки і помисли, а справжнє "Я" залишається в зародковому стані, тому що відсутні будь-які можливості для його становлення, внутрішня цілісність дитини порушується. 3 часом, у материнськодочірніх стосунках відбувається зміна ролей, донька стає не тільки розрадницею, порадницею, опорою, вона бере на себе відповідальність за благополуччя своєї матері. Така зміна ролей надзвичайно шкодить дочці, справляючи довготривалий плив на ії̈ самооцінку, упевненість і почуття власної цінності. Якщо матір має власні незадоволені потреби, вона не може віддати належне своїй дитині та, як наслідок, утворюється замкнене коло, де травмована мати наносить травму своїй дочці, а та, у свою чергу, переносить це у своє життя і на своїх дітей [3; 5].

Збірне поняття негативних наслідків патологічних відносин доньки та матері отримало назву материнська травма. Вона може виявлятись у придушенні своїх можливостей, надмірній терплячості до грубого ставлення інших чи навпаки - у жорсткості й домінантності, підвищенні емоційної турботи та чутливості за рахунок своїх інтересів, сприйнятті інших жінок як суперниць, харчових розладах, депресії, різноманітних залежностях, почутті провини тощо. Одним із найтяжчих вивів материнської травми $є$ самосаботаж, коли при деформації ролей у материнсько-дочірніх стосунках утворюється підсвідомий зв'язок між материнською любов'ю і самовиснаженням [5; 6].

Карл Юнг у своїх роботах уводить таке поняття, як комплекс матері, описуючи вплив матері як носія архетипічного образу, а також як особистості зі своїми реально існуючими рисами і характеристиками. Він виділив кілька видів його вияву, а саме:

Комплекс матері у вигляді гіпертрофії материнського інстинкту (характеризує жінок, для яких основною метою $€$ народження дітей). Чоловік для них відходить на другий план; він перш за все - інструмент для творення потомства, про який потрібно піклуватися так само, як і про дітей та домашне господарство. Навіть власна особистість для жінки із гіпертрофрією мате- 
ринського інстинкту набуває другорядного значення. Вона часто залишається абсолютно несвідомою до цього, живе лише для інших та ідентифрікується з усіма об'єктами її турботи. Народивши дітей, вона вже не мислить свого існування без них. Ї̈̈ Ерос розвивається виключно як материнський зв'язок, поки вона залишиться несвідомою як особистість. Несвідомий Ерос виражається в жадобі до влади. Жінки цього типу, хоча і продовжують "жити для інших", насправді не здатні на будь-які реальні жертви. Керуючись власними материнськими правами, безжальною волею до влади, яка виявляється у вигляді фантастичної наполегливості, вони часто досягають успіху в знищенні не тільки своєї особистості, а й особистостей своїх дітей. Чим менше свідома така мати щодо своєї особистості, тим сильніша і нерозбірливіша в засобах її несвідома воля до влади. Розум такої жінки не культивується як самоціль, але зазвичай залишається в первісному стані - примітивному, нескладному і безжальному [7].

К. Белл деякою мірою проливає світло на причини даних порушень. Вона вважає, що на взаємодію між матір'ю і дочкою, що стосується цієї сфрери, накладає відбиток материнське сприйняття дочки як істоти, що здатна викликати і переживати насолоду, і особливо відношення матері до дочірньої мастурбації, яка починається приблизно на п'ятнадцятому місяці життя. За Штерном, для включення певних способів поведінки в "Я"-концепції недостатньо, щоб така поведінка була просто терпимою. Поведінка має бути підкріпленою відгуком - а саме цього часто не вистачає дівочій мастурбації. К. Белл описує випадки кількох пацієнток, у яких виявилася специфічна травматична ситуація після того як мати протягом анальної фрази схвально визнала зростаючі здібності дочки, ії потенцію і креативність, поступово ці здатності в очах матері втратили своє значення. Після того як дівчатка з гордістю сприймали схвалення своєї анальної компетенції, зі своїми нинішніми ексгібіціоністськими бажаннями та зі своєю потребою в їх відображенні матір'ю, вони нерідко впираються в порожнечу. За словами дослідниці, часто це призводить до того, що ці потреби починають сприйматися як ганебні. Нарцисичні порушення матері щодо її цінності як жінки і невпевненість у материнській функції заважає їй позитивно оцінити свою доньку як маленьку дівчинку і майбутню жінку. Що в майбутньому призводить до витіснення Еросу в несвідоме і, відповідно, до вищеописаної гіпертрофії материнського інстинкту [1].

Комплекс матері як надмірний розвиток Еросу. Посилений Ерос надає ненормального значення особистості іншої людини. Ревнощі до матері й бажання перевершити ії стає лейтмотивом подальших дій, які часто виявляються згубними. Для жінки цього типу стають самоціллю романтичні та сенсаційні події, вона цікавиться одруженими чоловіками не стільки заради них самих, скільки через їхнє положення і, отже, можливості розбити шлюб, що є єдиною метою її зусиль. Коли ж мета досягнена, її інтерес зникає через відсутність материнського інстинкту. Цей тип характеризується значним ступенем несвідомості. Такі жінки зовсім сліпі стосовно того, що вони роблять [7].

Комплекс матері як ототожнення з матір'ю. Виявляється як параліч жіночої ініціативи дочки. Тут має місце складне відображення її особистості в матері завдяки тому, що вона несвідома як до свого материнського інстинкту, так і до Еросу. Все, що нагадує їй про материнство, відповідальність, особисті взаємини і еротичні потреби, породжує почуття невпевненості та змушує її відступати й шукати порятунку, природно, у своєї матері. Як різновид супержінки, якою дочка мимоволі захоплюється, мати пережила все те, що їй дочці тільки належить пережити. Остання задовольняється безкорисливою відданістю своїй матері, але в той же час під маскою абсолютної вірності та прихильності вона несвідомо прагне - майже проти своєї волі - тиранічно панувати над матір'ю [7].

Комплекс матері як супротив матері. Девіз цього типу: "Все, що завгодно, аби відрізнятися від Матері!" 3 одного боку, це уява, що ніколи не досягає ідентифрікації, з іншого - посилення Еросу, що виснажує себе в ревному опорі. Дочка цього типу знає, чого вона не хоче, але зазвичай вона перебуває в повній розгубленості, коли йдеться про вибір її власної долі. У негативній формі протистояння всі її інстинкти сконцентровані на матері, тому вони не приносять користі у формуванні її життя. Усі інстинктивні процеси наштовхуються на несподівані труднощі: або сексуальність не фрнкціонує як слід, або діти $€$ небажаними, чи материнські обов'язки здаються нестерпними, або подружні обов'язки викликають гнів і роздратування. Це цілком природно, бо коли запеклий опір владі матері в будь-якій формі стає головною метою життя, усе це не має ніякого стосунку до реальностей життя. Протистояння матері часто виявляється в менструальних порушеннях, нездатності до запліднення, відразі до вагітності, кровотечах, надмірній блювоті під час вагітності тощо. Мати може бути причиною жіночої дратівливості щодо оточуючих, грубого поводження. Також опір матері може іноді стати результатом спонтанного розвитку інтелекту з метою створення сфери інтересів, де для матері немає місця. Реальна мета цього розвитку полягає в руйнуванні влади матері інтелектуальною критикою і кращими знаннями, тобто у вигляді перерахування їй усіх ії̈ логічних помилок і недоліків в освіті. В основному інтелектуальний розвиток часто супроводжується появою чоловічих рис [7].

А. Міллер розглядає це питання з іншої позиції. Вона зазначає, що у кожної дитини є природна потреба бути разом із матір'ю, бути сприйнятою нею серйозно. Якщо ж мати проектує на дитину власні очікування, страхи і плани, дитина починає пристосовуватись до даного стану справ, а цілісність її особистості порушується. Як наслідок подібного ставлення, дослідниця виділяє депресію - "Те, що зазвичай іменувалося депресією і сприймалося як душевна порожнеча, відчуття безглуздості свого буття, страх перед можливим зубожінням і почуття самотності, я характеризую як трагічну втрату власного Я (або самовідчуження)" [3, с. 68]. А також, як зворотний її бік - прагнення до величі - "Прагнення до величі $\epsilon$ не що інше, як захисна реакція на душевний біль, викликаний утратою власного Я, що відбувається через небажання людини реально дивитися на речі" [3, с. 68]. Стан депресії не властивий тим, чиє почуття власної гідності природне і не залежить від володіння певними якостями. Втрата почуття самоцінності людини, що прагне до величі, свідчить про те, що власна її гідність була "повітряною кулею", що при стійкому вітрі злетіла, але потім луснула. У таких випадках не розвивається індивідуальність людини, яка пізніше могла б дати душевну опору. Людина, яка прагне до величі, уважає, що захоплення означає любов. До тих пір, поки людина не зрозуміє, що в дитинстві вона насправді потребувала поваги, розуміння і серйозного ставлення до себе з боку матері, вона буде боротися за право володіння цим субститутом любові [3].

Для емпіричного дослідження в контексті даної теми було обрано такі психодіагностичні методики: Опитувальник міжособистісної залежності Р. Гіршфільда, Методика диференціальної діагностики депресивних станів 
Зунге, Методика діагностики самооцінки психічних станів Айзенка. Метою було виявити дисфункціональні механізми адаптації жінок, що є наслідком патологічних взаємин із матір'ю - міжособова залежність, депресія, тривожність, фрустрація, агресія, ригідність. Для цього було сформовано вибірку із 40 жінок віком від 2025 років. За Е. Еріксоном, це період ранньої зрілості, що пов'язаний із виникненням проблеми близькості (інтимності). У цей період виявляється істинна сексуальність. Близькі стосунки із друзями чи коханими вимагають вірності, самопожертви і моральної сили. Це період створення сім'ї, що супроводжується любов'ю. Остання розуміється Е. Еріксоном в еротичному, романтичному і моральному смислах [8]. Стосунки з матір'ю фрормують у жінки її самовідчуття, світогляд, патерни поведінки, які проносяться через усе доросле життя та стають основою взаємодії з іншими людьми, партнерами та навіть із власними дітьми. Вибірка даного віку дозволяє поглянути на жінку уже як на сформовану особистість, а також висвітлює тенденції та особливості її інтеракцій із оточуючими.

Патологічні стосунки з матір'ю як правило супроводжуються зміною ролей, коли відповідальність за благополуччя матері перекладається на дитину, а потреби доньки ігноруються [5]. У даному емпіричному дослідженні ми припускаємо, що відсутність у матері постійного партнера (поряд з іншими факторами) каталізує та сприяє запуску цього процесу, що у свою чергу стає основою формування дисфункціональних механізмів адаптації жінок як вираження материнської травми. Це пояснюється тим, що донька в даних умовах стає єдиним об'єктом проекцій материнських страхів, бажань та незадоволених потреб, крім того, дитина стає єдиним джерелом любові для матері [4]. Саме тому половина жінок, які були залучені до вибірки, зростали у повних сім'ях, де матір мала постійного партнера, інша поло- вина - представниці сімей, де матері самі виховували дітей. Усе зазначене вище визначило напрям дослідження та значущість роботи, адже в нашій країні питання неповних сімей стоїть доволі гостро.

У ході нашого дослідження було отримано такі результати. Для кожної із заданих шкал вирахувані середнє значення, мода та стандартне відхилення, що дає нам можливість порівняти ступінь вираженості кожного показника для представниць двох груп вибірки та з'ясувати співвідношення між нормальними й екстремальними величинами даних показників, які можна трактувати як вияв дисфункціональних механізмів адаптації жінок.

Середнє значення рівня депресії для вибірки жінок із повних сімей становить 32 , а мода - 23, що перебуває в межах норми, тобто стан депресії не спостерігається, навіть якщо враховувати стандартне відхилення за даним показником. Емоційна опора на інших становить 47, мода - 42, що свідчить про середній рівень вираженості показника, який також спостерігається із врахуванням стандартного відхилення. Невпевненість у собі перебуває на середньому рівні за середнім значенням - 32,9, хоча мода - 40 - $€$ прикордонним значенням між середнім та високим рівнем. Та все таки ці показники не досягають екстремального вираження. Рівень прагнення до автономії коливається між середнім і високим, мода становить 33, тобто виражає високий ступінь вираженості прагнення, але стандартне відхилення показує імовірність обох рівнів. Міжособистісна залежність продемонстрована середнім рівнем вираженості як середнім значенням $(50,9)$, так і модою (38), а також із урахуванням стандартного відхилення. Тривожність, фррустрація, агресія та ригідність виражені середнім та низьким рівнем з урахуванням стандартного відхилення, мода демонструє низький ступінь вираженості (табл. 1).

Статистики показників для вибірки з повних сімей

\begin{tabular}{|c|c|c|c|c|c|c|c|c|c|}
\hline & РД & ЕОІ & НВС & ПА & М3 & Тривожність & Фрустрація & Агресія & Ригідність \\
\hline Середнє & 32,4762 & 47,3810 & 36,5238 & 32,9524 & 50,9524 & 8,5714 & 7,8095 & 9,8571 & 9,1429 \\
\hline Мода & 23,00 & 42,00 & 40,00 & 33,00 & 38,00 & 4,00 & 3,00 & 8,00 & 6,00 \\
\hline Станд. відхил. & 9,69339 & 6,89548 & 4,03261 & 6,17638 & 12,34697 & 4,74944 & 4,98617 & 4,32765 & 4,06553 \\
\hline
\end{tabular}

Аналізуючи результати вибірки представниць із неповних сімей, одразу помічаємо, що всі показники мають більший суепінь вираженості. Винятком $є$ прагнення до автономії, де навпаки, значення є нижчими. Рівень депресії перебуває в межах норми (35), але ми бачимо, як збільшене значення середнього значення, так і збільшення стандартного відхилення, що свідчить про більшу різноманітність відповідей досліджуваних. Емоційна опора на інших коливається між середнім і високим рівнями, особливо, ураховуючи стандартне відхилення показника. Невпевненість у собі представлене високим рівнем, при чому це стосується як стандартного значення $(39,6)$, так і моди (40). Потяг до автономії перебуває на середньому рівні за середнім значенням та модою. Міжособистісна залежність перебуває на межі між середнім і високим рівнем, особливо враховуючи стандартне відхилення. Тривожність, фрустрація, агресія та ригідність - на середньому рівні, хоча зі значним зростанням вираженості, порівнюючи із попередньою групою. Особливо великий розрив за показником тривожності, де результати наближаються до високого рівня вияву (табл. 2).

Статистики показників для вибірки з неповних сімей

\begin{tabular}{|c|c|c|c|c|c|c|c|c|c|}
\hline & РД & EOI & HBC & ПА & M3 & Тривожність & Фрустрація & Агресія & Ригідність \\
\hline Середнє & 35,1053 & 52,3684 & 39,6316 & 30,9474 & 61,0000 & 11,3684 & 8,8947 & 11,0526 & 10,7368 \\
\hline Мода & 22,00 & 39,00 & 40,00 & 33,00 & 35,00 & 14,00 & 13,00 & 9,00 & 5,00 \\
\hline Станд. відхил. & 13,42425 & 10,95552 & 5,38734 & 3,23992 & 16,44520 & 3,68496 & 5,07603 & 3,83657 & 3,96992 \\
\hline
\end{tabular}

Висновки. Отже, частіше за все причиною патологічних материнсько-дочірніх стосунків $€$ власні незадоволені потреби матері. Мати, народивши дитину, може несвідомо відчути, що у неї нарешті $€$ хтось, хто буде безумовно ії любити. Тоді вона неусвідомлено спробує за допомогою дитини задовольнити їх. Із часом, у материнсько-дочірніх стосунках відбувається зміна ролей, донька стає не тільки втішальницею, порадницею, опо- рою, вона бере на себе відповідальність за благополуччя своєї матері. Така зміна ролей надзвичайно шкодить дочці, справляючи довготривалий вплив на іï самооцінку, впевненість і почуття власної цінності.

Збірне поняття негативних наслідків патологічних відносин доньки та матері отримало назву материнська травма або комплекс матері, що може виявлятись у габітуації своїх можливостей; надмірній толерантності 
до грубого ставлення інших чи, навпаки, у жорсткості й домінантності; підвищенні емоційної турботи й чутливості за рахунок своїх інтересів; сприйнятті інших жінок як суперниць; харчових розладах; депресії; різноманітних залежностях; почутті провини. Одним із найтяжчих виявів материнської травми є самосаботаж. Юнг також виділив кілька виявів комплексу матері: гіпертрофія материнського інстинкту; надмірний розвиток Еросу; супротив матері; ототожнення з матір'ю.

Проаналізувавши результати дослідження, можна дійти висновку, що у представниць із неповних сімей усі показники мають більший ступінь вираженості. Це свідчить про те, що для жінок, чиї матері не мають постійного партнера, а значить вони концентрують свою увагу переважно на доньках, більш притаманно переживати стани депресії, тривожності, агресії та ригідності високої інтенсивності, які, опираючись на проаналізовану літературу, можна трактувати як дисфункціональні механізми адаптації внаслідок материнської травми.

Стає очевидним, що гармонійні стосунки з матір'ю $€$ основою формування повноцінної особистості, тоді як порушення природної взаємодії у вигляді жорстокої боротьби за схожість і відмінність призводять до неадекватного сприйняття світу та себе самого, що замкненим колом переноситься на всі наступні покоління.

Список використаних джерел

1. Белл К. Мать и дочь - трудное равновесие / Карин Белл [Электронний ресурс] // Психотерапевтич. журн. - 1998. - № 1. - Режим доступа: http://flogiston.ru/articles/therapy/mother_n_dauther (дата обращения 20.03.2018).

2. Эльячеффф К. Дочки-матери. Третий лишний? ; пер. с фрранц./ К. Эльячефф, Н. Эйниш. - К. : Институт общегуманитарных исследований, 2006. - 448 с.

А. Сичкарь, студ

Киевский национальный университет имени Тараса Шевченко, Киев
3. Миллер А. Драма одареного ребенка и поиск собственного Я / пер. с нем. / А. Миллер. - М. : Академический Проект, 2001. - 144 с.

4. Петрушин С.В. Любовь и другие человеческие отношения / С. В. Петрушин. - Изд. 3-е, испр. - СПб. : Речь, 2011. - 141 с.

5. Уебстер Б. Когда стыд на вкус как материнская забота: трагедія дочерей, на которых возложили родительские роли / Беттани Уебстер [Электронний ресурс]. - Режим доступа: http://9journal. com.ua (дата обращения 2.03.2018).

6. Уебстер Б. О травматических отношениях с матерью / Беттани Уебстер [Электронний ресурс]. - Режим доступа: (дата обращения 2.03.2018).

7. Юнг К.-Г. Душа и миф: шесть архетипов ; пер. с англ. / Карл-Густав Юнг. К. : Государственная библиотека Украины для юношества, 1996. - 384 с.

8. Яшкова А.Н. Возрастная психология: учебное пособие / А. Н. Яшкова, Н. Ф. Сухарева. - Саранск, 2011. - 101 с.

\section{Reference}

1. Bell K. Mat i doch - trudnoe ravnovesie/ Karin Bell [Elektronnii resurs] // Psikhoterapevticheskii zhurnal. 1998. - № 1. - Rezhim dostupa: bhttp://flogiston.ru/articles/therapy/mother $\mathrm{n}$ dauther (data obrashcheniia 20.03.2018).

2. Eliacheff K. Dochki-materi. 3-tii lishnii? [per. s frants] / K. Eliacheff, N. Einish. - K. : Institut obshchegumanitarnykh issledovanii, 2006. - 448 s.

3. Miller A. Drama odarennogo rebenka i poisk sobstvennogo la [per. s nem.] / A. Miller. - M. Akademicheskii Proekt, 2001. - 144 s.

4. Petrushin S. V. Liubov i drugie chelovecheskie otnosheniia/ S. V. Petrushin. - Izd. 3-e, ispr. - SPb. : Rech, 2011. - $141 \mathrm{~s}$.

5. Uebster B. Kogda styd na vkus kak materinskaia zabota: tragediia docherei, na kotorykh vozlozhili roditelskie roli / Bettani Uebster. [Elektronnii resurs] - Rezhim dostupa: http://9journal.com.ua (data obrashcheniia 2.03.2018).

6. Uebster B. O travmaticheskikh otnosheniiakh s materiu/ Bettani Uebster [Elektronnii resurs] - Rezhim dostupa: (data obrashcheniia 2.03.2018). - Nazvanie s ekrana.

7. lung K.-G. Dusha i mif: shest arkhetipov. [per. s angl.] / Karl-Gustav lung. K. : Gosudarstvennaia biblioteka Ukrainy dlia iunoshestva, 1996. - $384 \mathrm{~s}$.

8. lashkova A. N. Vozrastnaia psikhologiia : uchebnoe posobie / A. N. lashkova, N. F. Sukhareva. - Saransk, 2011. - $101 \mathrm{~s}$.

Надійшла до редколегії 06.11.18

\section{ДИСФУНКЦИОНАЛЬНЫЕ МЕХАНИЗМЫ АДАПТАЦИИ КАК СЛЕДСТВИЕ ПАТОЛОГИЧЕСКИХ ОТНОШЕНИЙ ДОЧЕРИ И МАТЕРИ}

Поднимается вопрос о дисфункциональных механизмах адаптации у женщин как следствие патологических взаимоотношений с матерью. Особое внимание уделяется таким из них: межличностная зависимость, депрессия, тревожность, фрустрация, агрессия, ригидность.

Результатом исследования стало доказательство того, что у представительниц из неполны хсемей все заданные показатели (межличностная зависимость, депрессия, тревожность, фрустрация, агрессия, ригидность) болем выражены. Это означает, что отсутствие у матери постоянного партнера (наряду с другими факторами, которые освещены в статье) катализирует и способствует запуску процесса формирования патологических отношений между дочерью и матерью, что в свою очередь становится основой формирования дисфункциональных механизмов адаптации у дочери как выражение материн ской травмы. Это объясняется тем, что дочь в даннях условиях становится единственным объектом проекций материнських страхов, желаний и неудовлетворенных потребностей, кроме того, она становится единственным источником любви.

Ключевые слова: материнская травма, комплекс матери, дисфункциональные механизмы адаптации, проекция, "псевдоличность".

H. Sichkar, student

Taras Shevchenko National University of Kyiv, Kyiv

\section{DYSFUNCTIONAL MECHANISMS OF ADAPTATIONAS A RESULT OF PATHOLOGICAL RELATIONSHIPS BETWEEN DAUGHTER AND MOTHER}

The article raises the question of women's dysfunctional mechanisms of adaptation as a consequence of pathological relationships with the mother. Particular attention is paid to such of them: interpersonal dependence, depression, anxiety, frustration, aggression, rigidity. The Hirschfeld Interpersonal Dependency Inventory, the Zung Self-Rating Depression Scale and the Eysenck Personality Questionnaire were used for an empirical study. In order to achieve these goals, a sample of $\mathbf{4 0}$ women aged 20 to 25 years was formed. A sample of this age allows you to look at a woman as an already established personality, and highlights the trends and characteristics of her interactions with others. The result of the study proved that the representatives of single-parent families have a greater degree of severity for all the indicators were given (interpersonal dependence, depression, anxiety, frustration, aggression, rigidity). This means that the absence of a permanent mother's partner (along with other factors covered in the article) catalyzes and promotes the process of forming the pathological relationship between a daughter and mother, which in turn becomes the basis for the formation of dysfunctional mechanisms of adaptation to the daughter as an expression of maternal injury. Maternal trauma or a mother complex is defined as the collective concept of a daughter and mother pathological relationship negative consequences. This is explained by the fact that the daughter in these conditions becomes the only one object of the projections of mother's fears, desires and dissatisfied needs, besides, she becomes the only source of love. A harmonious relationship with the mother is the basis for a full-fledged personality formation, while a natural interaction violation in the form of a fierce struggle for similarity and difference leads to an inadequate perception of the world and oneself, which is transferred to all subsequent generations in a closed circle.

Keywords: maternal trauma, mother complex, dysfunctional mechanisms of adaptation, projection, "pseudo personality". 